\title{
Anodic slimes formation in copper electrowinning ${ }^{(\cdot)}$
}

\author{
J. Ipinza*, J.P. Ibáñez*, F. Vergara** and A. Pagliero**
}

\begin{abstract}
The slime formation in acidic electrolytes of copper with several metallic impurities has been studied. $\mathrm{On} \mathrm{Pb}-\mathrm{Ca}-\mathrm{Sn}$ anode surface firstly the formation of $\mathrm{PbSO}_{4}$ takes place, then, it is transformed in $\mathrm{PbO}_{2}$, which covers the anode surface. It was experimentally established the formation of a manganese dioxide double layer at the anode. This layer was always composed of a thick external layer of non-adhering and easily removable scales, and of a thin internal layer, which adheres relatively well to the surface of the electrode. It was found that the manganese dioxide present in the slime is of different nature: a nonadhering layer produced by electrolysis $\left(\varepsilon-\mathrm{MnO}_{2}\right)$ on the $\mathrm{PbO}_{2}$ surface and a pure chemical precipitate in the solution $\left(\beta-\mathrm{MnO}_{2}\right)$. Lead sulfate was found on the $\beta-\mathrm{MnO}_{2}$ layer when iron was in the electrolyte. When arsenic or antimony was present in the electrolyte, the slime was lead sulfate and amorphous compounds of those ions. Slime of Chilean electrowinning (EW) plants is also discussed.
\end{abstract}

Keywords Metallic impurities. Anodic slimes. Copper electrolytes. Electrowinning. Manganese dioxides.

\section{Formación de borras anódicas en electroobtención de cobre}

Resumen

Se estudió la formación de borras anódicas debido a la presencia de varias impurezas metálicas en electrólitos de cobre. Sobre la superficie de un ánodo de $\mathrm{Pb}$-Ca-Sn se forma primero $\mathrm{PbSO}_{4}$ y luego se transforma en $\mathrm{PbO}_{2}$, el cual cubre la superficie del ánodo. Se estableció experimentalmente la formación de una doble capa de dióxido de manganeso en el ánodo. Esta estuvo siempre compuesta por una capa externa gruesa, no adherente y de fácil remoción, y otra interna delgada y adherida a la superficie del electrodo. Se encontró que los óxidos de manganeso en las borras eran de distinta naturaleza: una capa no adherente producida por electrólisis sobre la superficie de $\mathrm{PbO}_{2}\left(\varepsilon-\mathrm{MnO}_{2}\right)$ y una producida sólo por precipitación química en la solución $\left(\beta-\mathrm{MnO}_{2}\right)$. Al existir hierro en el electrólito se encontró sulfato de plomo sobre esta última capa. En el caso de electrólitos con arsénico y antimonio, en la borra se encontró sulfato de plomo y compuestos amorfos de estos iones. La generación de borras en plantas chilenas de electro-obtención (EO) también se discute.

Palabras clave Impurezas metálicas. Borras anódicas. Electrólitos de cobre. Electroobtención. Dióxidos de manganeso.

\section{INTRODUCTION}

The world-wide increase of aqueous processing (Leaching, Solvent Extraction (SX) and electrowinning $(E W)$ ) for production of electrolytic copper is due to a lower operating cost in comparison with flotation followed by smelting. Furthermore, the aqueous processing is considered more environmental sustainable than the pyrometallurgical one. However, the so called hydrometallurgical route of production has its own environmental issues, one of the most important is the storage of the slimes generated.

During the solvent extraction process, some impurities escape and report in the electrolyte. Although the concentrations of such impurities are not high enough to substantially affect the anode corrosion and deposit quality, they can build-up in closed circuit (SX-EW), where they are likely to interfere with the electrowinning process ${ }^{[1]}$.

The EW of copper is an electrochemical reduction process where cupric ions from the

(•) Trabajo recibido el día 7 de abril de 2003 y aceptado en su forma final el día 25 de febrero de 2004.

(*) Departamento de Ingeniería Metalurgia, Universidad Arturo Prat, Av. Arturo Prat 2120, Iquique, Chile.

(**) Departamento de Ingeniería Metalúrgica, Universidad de Concepción, Edmundo Larenas 270, Concepción, Chile. 
electrolyte of SX is deposited on the surface of a cathode, which is normally of stainless steel. Deposition of copper is achieved by a difference of potential between the cathode and the anode $(\mathrm{Pb}$ $\mathrm{Ca}-\mathrm{Sn}$ alloy) generated by the application of an external electrical field. In the anode the current applied oxidizes water, which gives the electrons required by the reduction reaction of copper in the cathode. This electrochemical process generates the marketable cathodes of copper and the corrosion of the anode.

The particles detached from the anode by corrosion and suspended solids in the electrolyte (colloids and organic from SX, precipitates among others) are known as slime, which accumulates at the bottom of EW cells. If the cells are not periodically cleaned up, the slime layer increases and due to the circulation of the electrolyte, the slime can float causing contamination of the cathodes $^{[2-7]}$.

During chemical or bacterial leaching of minerals not only copper is dissolved but also an important number of impurities, which may reach the EW plant due to a decrease of the extractant selectivity and/or physical entrapment in the SX circuit. Depending on their concentration, the impurities can produce severe damage to the anodes. There is abundant technical literature regarding the effect of each impurity on the anode in acid media ${ }^{[8-}$ ${ }^{21]}$. However, there is a lack of information about the synergetic effect of the impurities on the anode corrosion and slime generation.

The aim of this work is to study the origin of slimes under controlled conditions in the laboratory and to understand the effect of the manganese on the slime formation and its interaction with iron. A preliminary comparison with slimes formed from electrolytes having arsenic and antimony ions is made as well. Finally, the Chilean industrial data on slime production is analyzed.

\section{EXPERIMENTAL}

Voltametric tests were made in a Voltalab 40 (Radiometer Analytical) having a potentiostat (P6Z301) and an electrochemical software for data acquisition and data processing (Volta Master 4 v.1.2). The cyclic voltametry considered potential scan between -1000 and $1900 \mathrm{mV}$ at $5 \mathrm{mV} / \mathrm{s}$.

All reagents were of analytical grade and were used with no further purification. A matrix of 180 $\mathrm{g} / \mathrm{l}$ of aqueous sulfuric acid was used in all the experiments unless otherwise specified.' Manganese solutions having $0.07,0.7,1.0,1.4,3.0,4.0,5.0$ and $6.0 \mathrm{~g} / \mathrm{l}$ of manganous ion were obtained by dissolving the respective amount of manganese sulfate. The relative high values of manganese concentration allows to generate manganese oxide in a short period of time, which emulates the generation of manganese oxide layers at low manganese concentration in a long period of time as observed in the EW plants. The last figure is due to the closed circuit operation between the stripping stage of SX and EW.

Potentiodynamic experiments at $2.0 \mathrm{~V}$ (SHE) during $3 \mathrm{~h}$ were carried out in a rectangular cell made of PVC with capacity for 4.01 of electrolyte. The working electrode (anode) was made of an alloy having 98.598 \% Pb, 0.073 \% Ca and $1.331 \%$ Sn. The effective area of the anode was $7 \mathrm{~cm}^{2}$. The auxiliary and reference electrodes were of platinum and of $\mathrm{Ag} / \mathrm{AgCl}$, respectively, i.e., a cell array without a cathode. Values of potentials are given as the standard hydrogen electrode (SHE) The working electrode was thoroughly polished and washed, once installed in the cell a further electrolytic cleaning was made at $-1.5 \mathrm{~V}$ during $0.25 \mathrm{~h}$. The constant potential applied to the cell was supplied by a potentiostatgalvanostat (Amel Instruments Model 2049). The electrolyte was recirculated to the cell by a pulse pump at $0.6 \mathrm{l} / \mathrm{h}$. All experiments were conducted

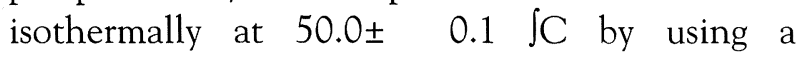
thermostatically controlled water bath.

In this study the presence of organic additive and cobalt sulfate was not considered.

At the end of each experiment the solids formed on the anode surface were analyzed by using $\mathrm{X}$ ray diffraction (XRD), scanning electron microscopy (SEM) and electron probe microanalysis (EPMA). The slimes generated were collected from the bottom of the cell, washed with distilled water and ethanol for a fast dry and finally were stored under a free moisture and reduced pressure atmosphere. Slimes were analyzed by the same techniques.

\section{RESULTS AND DISCUSSIONS}

The polarization test between -1.0 and $1.9 \mathrm{~V}$ with no manganese and with $4.0 \mathrm{~g} / \mathrm{l}$ of $\mathrm{Mn}^{2+}$ were made in order to include the reactions in the stability zone of $\mathrm{Pb}^{2+}, \mathrm{Pb}^{4+}$ and oxygen evolution. Figure 1 shows that manganese is able to shift the water decomposition reaction in acid by more than 100 $\mathrm{mV}$. Furthermore, it is observed a decrease in the reduction peak of $\mathrm{PbO}_{2}$ by the presence of 


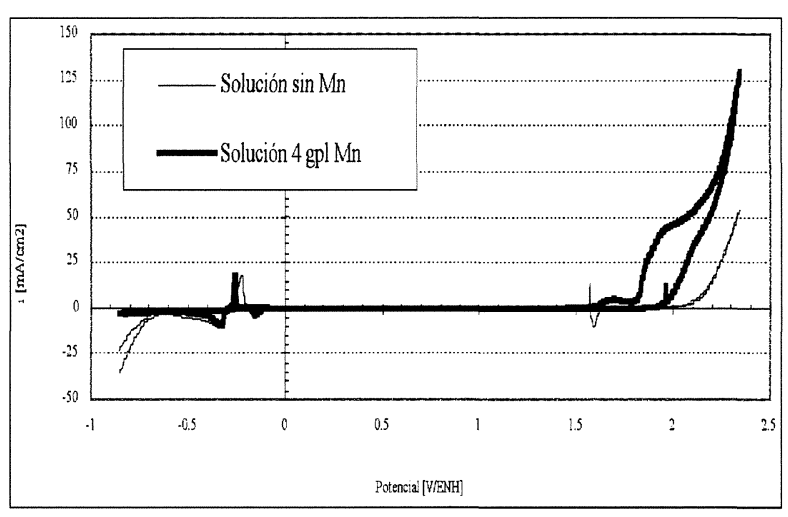

Figure 1. Voltametric pattern of electrolyte having no manganese and with $4 \mathrm{~g} / \mathrm{l}$ of $\mathrm{Mn}^{2+}$.

Figura 1. Patrón voltamétrico de electrólito sin manganeso y con $4 \mathrm{~g} / \mathrm{l}$ de $\mathrm{Mn}^{2+}$.

manganese. Then, a lower corrosion rate of the anode is expected.

The main consequence of the oxygen generation in the anode is the formation of $\mathrm{PbO}$, $\beta-\mathrm{PbO}_{2}, \alpha-\mathrm{PbO}_{2}, \mathrm{PbSO}_{4}$ and complex sulfates on its surface. The nature of the corrosion products formed during anodic polarization of lead in sulfuric acid changes with the potential and $\mathrm{pH}$. This, in turn, affects the corrosion rate of the anodes. It is well known that the maximum corrosion rate occurs when the potential is slightly lower than that for $\mathrm{PbO}_{2} / \mathrm{PbSO}_{4}(1.685 \mathrm{~V})$, whose corrosion products are $\mathrm{PbSO}_{4}, \mathrm{PbO}$ and $\alpha-\mathrm{PbO}_{2}$. At potentials higher than $1.685 \mathrm{~V}$, the dominant process is the oxidation of $\mathrm{PbSO}_{4}$ to $\beta-\mathrm{PbO}_{2}$ with small formation of $\alpha-\mathrm{PbO}_{2}$, therefore, the anode corrosion rate decreases. However, by rising the potential over $2 \mathrm{~V}$, the predominant process is the generation of oxygen, nevertheless, the diffusion rates of $\mathrm{OH}^{-}$toward the $\beta-\mathrm{PbO}_{2}$ and of $\alpha-\mathrm{PbO}_{2}$ toward the anode surface rise, hence there is an increase of the corrosion rate.

It is well known that both types of $\mathrm{PbO}_{2}$ are markedly different. The $\beta-\mathrm{PbO}_{2}$ conducts electricity, since the oxidation of water will occur on the surface of this layer, a rise in the $\beta-\mathrm{PbO}_{2}$ forming rate will result in a lower corrosion rate. On the other hand, $\alpha-\mathrm{PbO}_{2}$ do not conduct electric energy, so it partially passives the anode surface, then the oxidation reactions occur directly on the non protected area of the anode, increasing the corrosion rate ${ }^{[22-27]}$

Figure 2a shows a scanning electron micrograph of an anode surface after an electrolytic test of sulfuric acid and figure $2 \mathrm{~b}$ shows the EPMA analysis on that surface, which has been used to compare with further deposits. XRD analysis shows presence of lead oxides typically formed at the working potential $(2 \mathrm{~V})$.

Figure 3a shows a SEM photograph of an homogeneous and massive deposit formed on the anode surface when manganous ions were present $(0.7 \mathrm{~g} / \mathrm{l})$. EPMA analysis (Fig. 3b) shows the presence of manganese and lead on this layer. However, XRD shows only the pattern of lead (oxides and sulfate).

Lead in the electrolyte was found to be related with the manganese concentration in the electrolyte. This was associated to deposits formed at higher concentrations of manganese, which were massive and highly porous. EPMA and XRD analysis of these deposits indicated an amorphous nature. Deposits exhibit a clear tendency to be
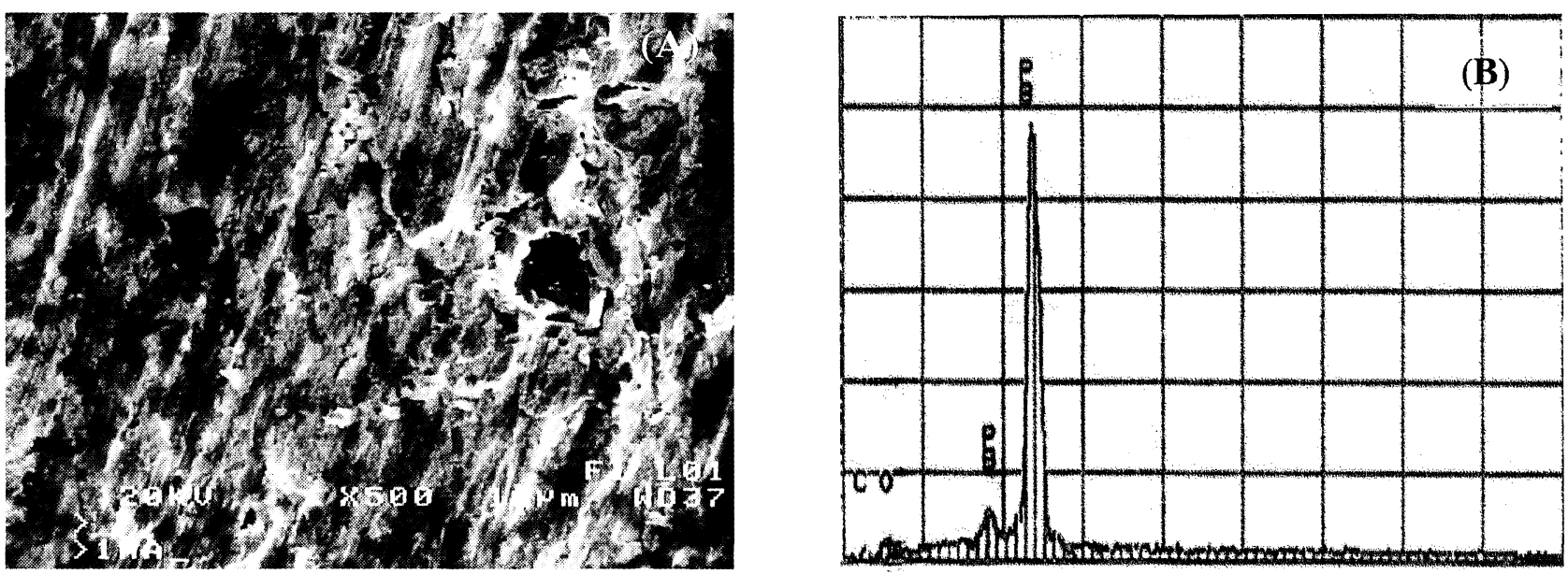

Figure 2. SEM image (A) and EPMA analysis (B) of the anode surface after electrolysis with no metallic impurities.

Figura 2. Imagen SEM (A) y análisis EPMA (B) de la superficie anódica después de una electrólisis sin impurezas metálicas. 

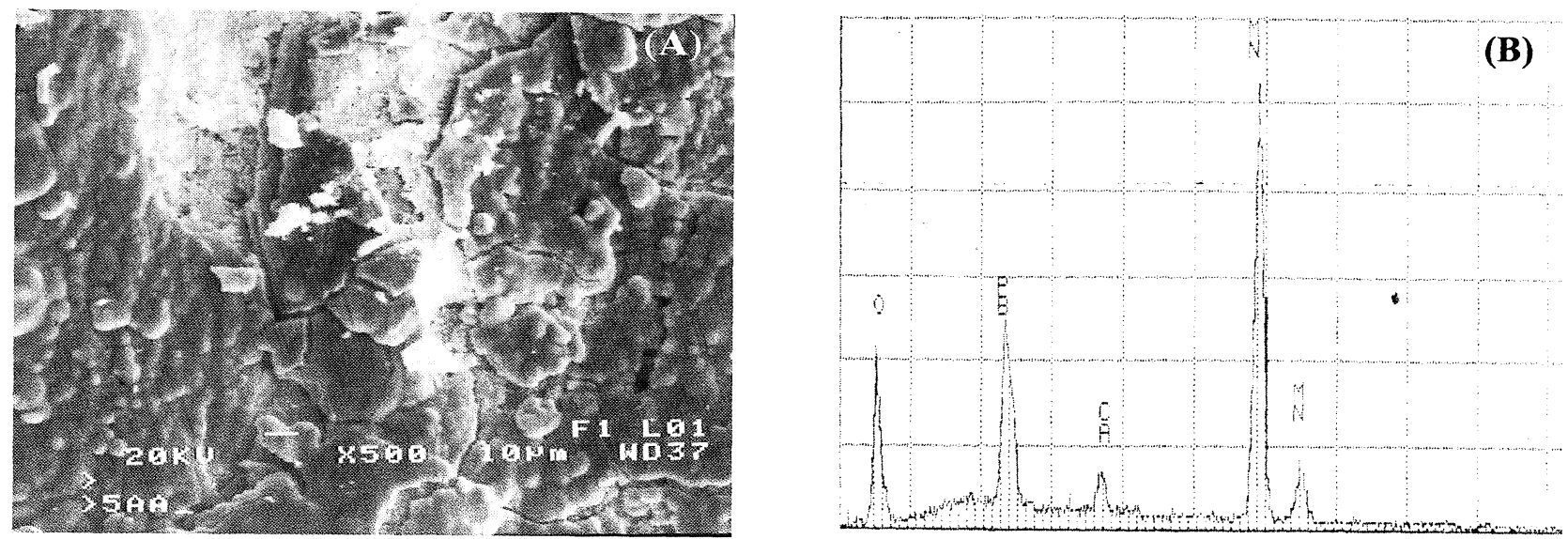

Figure 3. SEM image (A) and EPMA analysis (B) of the deposit obtained after electrolysis with an electrolyte with $0.7 \mathrm{~g} / \mathrm{l}$ of $\mathrm{Mn}^{2+}$ at $2 \mathrm{~V}$ during $3 \mathrm{~h}$.

Figura 3. Imagen SEM (A) y análisis EPMA (B) del depósito producido por electrólisis a $2 \mathrm{~V}$ de un electrólito con $0,7 \mathrm{~g} / \mathrm{l}$ de $\mathrm{Mn}^{2+}$ durante $3 \mathrm{~h}$.

detached by gravity along with the protective layer, which allows the contact between the clean anode surface and the electrolyte, as it is shown in figure 4. Photographs (A) and (B) shows the anode surface when 4 and $6 \mathrm{~g} / \mathrm{l}$ of $\mathrm{Mn}^{2+}$ were used, respectively. It appears clear that the deposit of the amorphous manganese is of the arborescent type (Fig. 4a) and it is detached from the anode surface. Figure $4 \mathrm{~b}$ shows that the anode is partially exposed by the detachment of the manganese layer. This indicates that the amorphous layer of manganese oxide behaves as a protective layer of the anode for low manganous ions concentration in the

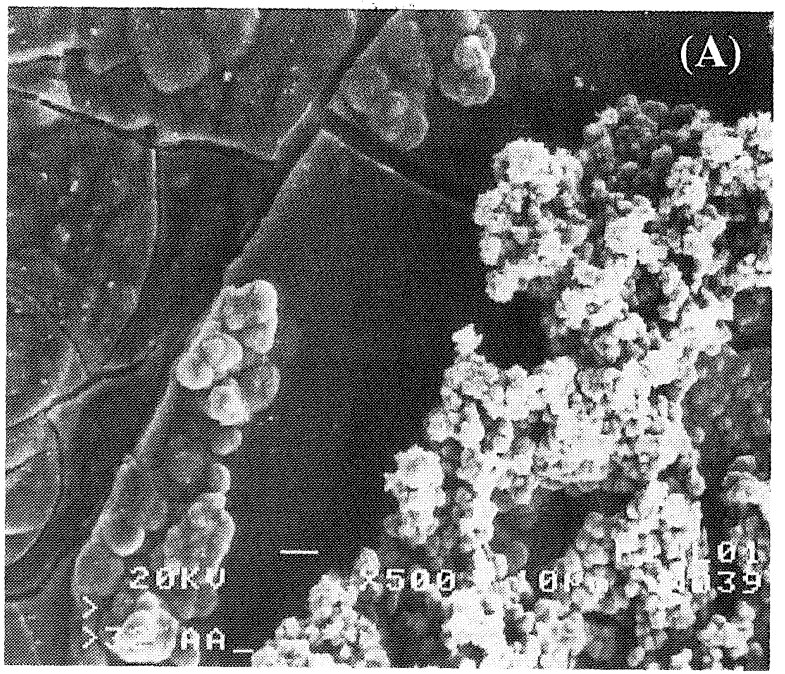

electrolyte. This conclusion also agrees with the voltametry findings (Fig. 1). As it was found by Ipinza et al. ${ }^{[28]}$, that for concentrations below around $1.4 \mathrm{~g} / \mathrm{l}$ of $\mathrm{Mn}^{2+}$ there is a protective effect of the manganese layer on the anode.

When $0.7 \mathrm{~g} / \mathrm{l}$ of manganous ions were used, a high slime formation rate was observed. Figure $5 \mathrm{a}$ shows an EPMA spectrum of this slime, which indicates a higher content of the manganese species in comparison with those of lead. This fact indicates that manganous ions promote the formation of precipitates that reports in to the slimes, which are different from the anode corrosion. The XRD

Figure 4. SEM images of anode surfaces after electrolysis of $3 \mathrm{~h}$ with $2 \mathrm{~V}$ for electrolyte having 4 and $6 \mathrm{~g} / \mathrm{l}$ of $\mathrm{Mn}^{2+}$, images $(A)$ and $(B)$, respectively.

Figura 4. Imágenes SEM de la superficie del ánodo después de 3 horas de electrólisis a $2 \mathrm{~V}$ de electrólitos conteniendo 4 y 6 $\mathrm{g} / \mathrm{l}$ de $\mathrm{Mn}^{2+}$ fotografías $(A)$ y $(B)$, respectivamente. 
pattern of the slime is given in Figure 5b, which shows that it is formed by both tetragonal and hexagonal manganese oxides. It appears that the manganous slime is being formed by two different routes; one that forms the hexagonal oxide and the second one the tetragonal type. It can be hypothesized that one compound could correspond to an electrolytic deposit and the second one could be formed by a precipitation reaction.

Figure 6 shows a SEM photograph (A) and XRD pattern (B) of free foils collected directly from the anode surface. The pattern clearly shows that these foils are the hexagonal type of manganese dioxide $\left(\varepsilon-\mathrm{MnO}_{2}\right)$. Furthermore, it can be deducted from the XRD pattern that this oxide shows low crystallinity.

Figures 2, 5 and 6 support the assumption that the manganous deposit on the anode surface occurs initially as an amorphous structure, which slowly crystallize in contact with the electrolyte, at a rate probably controlled by the manganous ion concentration. Further, a fraction of the slime formed during the electrolytic test, is detached from the solids covering the anode surface. The electrolytic reaction for $\varepsilon-\mathrm{MnO}_{2}$ generation can be represented by the following reaction:
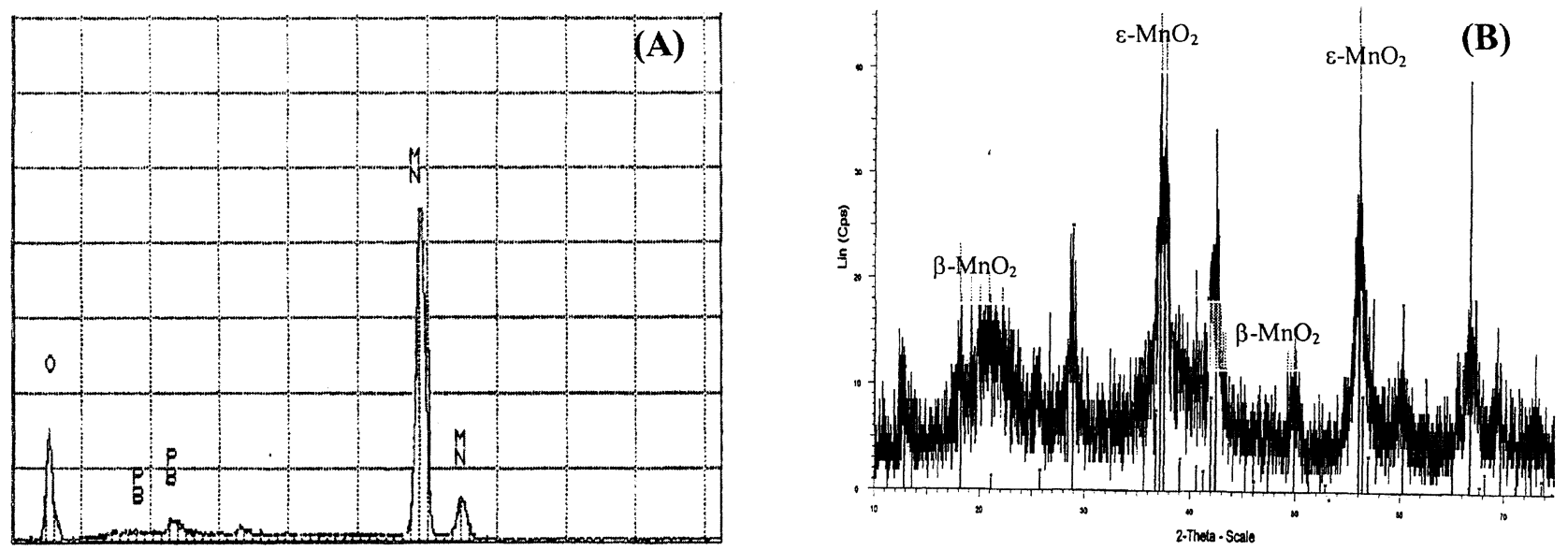

Figure 5. EPMA and XRD patterns (Anode: Cu-WL1:1.5406) obtained for slime generated by electrolysis of electrolyte with 0.7 $\mathrm{g} / \mathrm{l}$ of $\mathrm{Mn}^{2+}$, image $(\mathrm{A})$ and $(\mathrm{B})$, respectively.

Figura 5. Patrones de EPMA y de XRD (ánodo: Cu WL1:1.5406) obtenidos para borras generadas por electrólisis de 0,7 g/l de $\mathrm{Mn}^{2+}$, imagen $(A)$ y $(B)$, respectivamente.

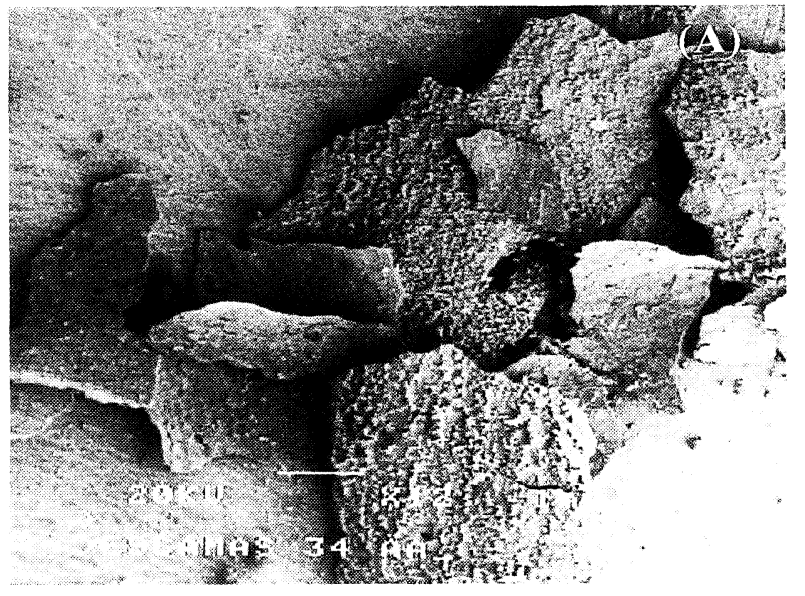

Figure 6. SEM image (A) and XRD pattern (Anode: surface after electrolysis of electrolyte with $0.7 \mathrm{~g} / / \mathrm{Mn}^{2+}$.

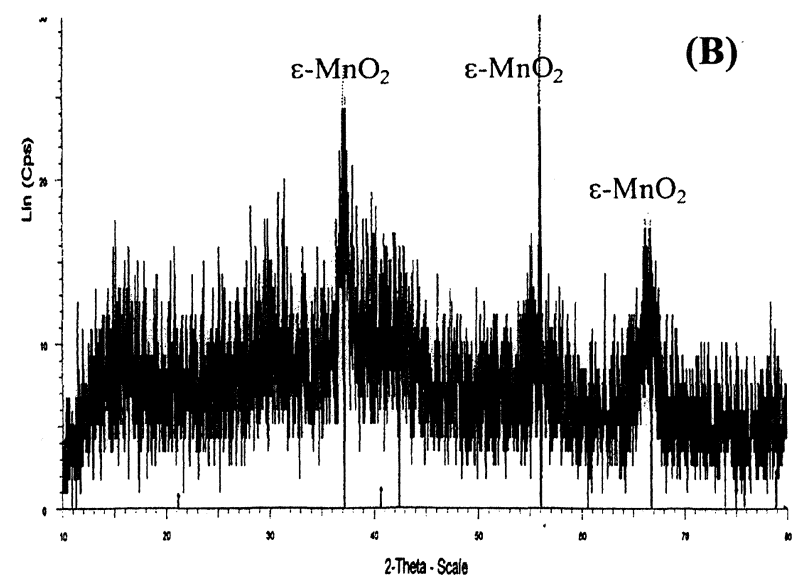

Figura 6. Imagen SEM (A) y patrón de XRD (B) (ánodo: Cu WL1:1.5406) (B) del sólido recolectado desde la superficie del ánodo después de una electrólisis con 0,7 $\mathrm{g} / \mathrm{/} \mathrm{de} \mathrm{Mn}^{2+}$. 
$\mathrm{MnSO}_{4}+2 \mathrm{H}_{2} \mathrm{O}=\mathrm{MnO}_{2}+\mathrm{H}_{2} \mathrm{SO}_{4}+2 \mathrm{H}^{+}+2 \mathrm{e}$

Another fraction of slime could be produced by a precipitation reaction in the electrodeelectrolyte interfase, which can be catalyzed by $\mathrm{PbO}_{2}$ active sites. It was observed that the precipitation begins with the electrolysis simultaneously with permanganate formation (markedly violet coloration). This fraction of the slime could be tetragonal manganese oxide $\left(\beta-\mathrm{MnO}_{2}\right)$. The formation of this oxide may be represented by the following reactions:

$\mathrm{MnSO}_{4}+4 \mathrm{H}_{2} \mathrm{O}=\mathrm{MnO}_{4}^{-}+\mathrm{H}_{2} \mathrm{SO}_{4}+6 \mathrm{H}^{+}+5 \mathrm{e}$

$3 \mathrm{MnSO}_{4}+2 \mathrm{HMnO}_{4}+2 \mathrm{H}_{2} \mathrm{O}=2 \mathrm{MnO}_{2}+3 \mathrm{H}_{2} \mathrm{SO}_{4}$

The presence of $4 \mathrm{~g} / \mathrm{l}$ of ferrous ions in the electrolyte with different manganese concentrations $(0.07$ to $4 \mathrm{~g} / \mathrm{l})$ inhibits the formation of $\beta-\mathrm{MnO}_{2}$ based slime because ferrous ions will be oxidized preferentially to manganese ions, according to reactions (4) and (5), therefore, reaction (3) will be prevented:

$$
\begin{gathered}
\mathrm{Mn}^{+3}+\mathrm{Fe}^{2+}=\mathrm{Mn}^{2+}+\mathrm{Fe}^{3+} \\
\mathrm{MnO}_{4}^{-}+5 \mathrm{Fe}^{2+}+8 \mathrm{H}^{+}=\mathrm{Mn}^{2+}+5 \mathrm{Fe}^{3+}+4 \mathrm{H}_{2} \mathrm{O}
\end{gathered}
$$

It was observed that the presence of iron in electrolytes with $1.4 \mathrm{~g} / \mathrm{l} \mathrm{Mn}^{2+}$ promotes the precipitation of lead compounds on the amorphous manganese layer. SEM observation (Fig. 7a) shows that sulfate has a random-oriented needles habit. The EPMA spectrum (Fig. 7b) shows that the main component on the surface was lead, which is the opposite behavior to that observed when no iron was present in the electrolyte (Fig. 3).

Similar behavior in slime formation when electrolytic experiments were conducted with metalloid impurities such as arsenic and antimony was found previously ${ }^{[29}$ and 30$]$. These ions are found in electrorefining (ER) electrolytes, however, the actual trend in leaching of copper sulphide minerals, which in Chile have significant amount of these ions, could suggest their presence in EW plants in the near future. Furthermore, when diluted industrial ER bleeds are oxidized in the anode during a reactive electrodialysis test, the slime generated is basically lead sulfate and an amorphous compounds of arsenic and antimony ${ }^{[30]}$.

A common electrolyte composition of Chilean EW plants is given in Table I. Data was divided in two large groups: low slime producers and high slime producers.

The table shows that a lower manganese concentration in presence of iron resulted in a lower rate of slime generation, which is in agreement with the laboratory test work ${ }^{[28]}$. Since iron and manganese concentrations in the inset electrolyte present a significant difference between high and low slime producers, it could be possible to state that the combined effect of these impurities are the base for developing a master parameter to improve the control of slime production. The addition of cobalt has a beneficial effect on the
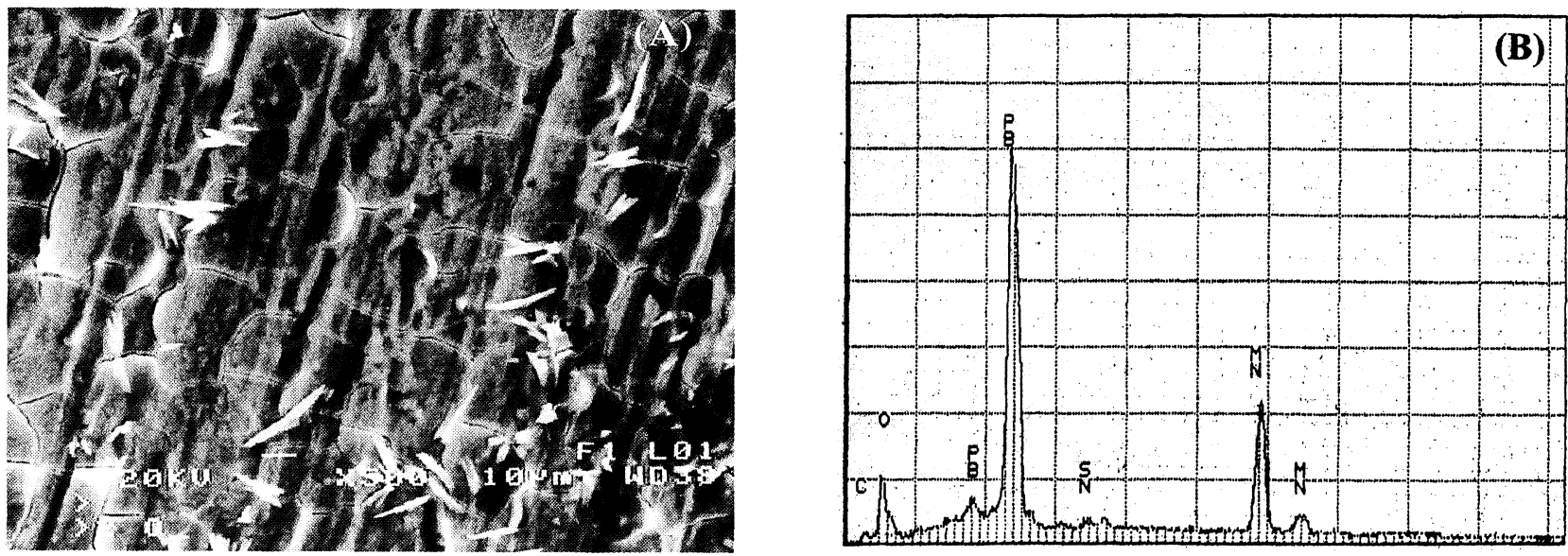

Figure 7. SEM image (A) and EPMA spectrum (B) of the anode surface when electrolysis was carried out with electrolyte having both iron and manganese ions.

Figura 7. Imagen SEM (A) y espectro EPMA (B) de la superficie del ánodo después de la electrólisis de un electrólito que contenía iones de hierro y manganeso. 
Table I. Typical EW electrolyte composition from Chilean plants

Tabla I. Composición del electrólito de plantas de EO chilenas

\begin{tabular}{lcc}
\hline $\begin{array}{l}\text { Parameter } \\
\text { (input) }\end{array}$ & $\begin{array}{c}\text { High Slime } \\
\text { Producers }\end{array}$ & $\begin{array}{c}\text { Low Slime } \\
\text { Producer }\end{array}$ \\
\hline $\mathrm{kg} \mathrm{Pb} /$ year/cell & 456.0 & 78.0 \\
$\mathrm{Flux}\left(\mathrm{m}^{3} / \mathrm{h}\right)$ & 25.1 & 15.3 \\
Temperature $\left({ }^{\circ} \mathrm{C}\right)$ & 49.8 & 45.3 \\
$\mathrm{Cu}(\mathrm{g} / \mathrm{l})$ & 42.5 & 41.2 \\
$\mathrm{Cl}^{-}(\mathrm{mg} / \mathrm{l})$ & 17.3 & 22.0 \\
$\mathrm{Co}^{2+}(\mathrm{mg} / \mathrm{l})$ & 125.8 & 127.2 \\
$\mathrm{Fe}^{2+}(\mathrm{mg} / \mathrm{l})$ & 562.1 & 69.0 \\
$\mathrm{Fetotal}(\mathrm{mg} / \mathrm{l})$ & 1336.5 & 1079.2 \\
$\mathrm{Mn} 2+(\mathrm{mg} / \mathrm{l})$ & 26.4 & 7.0 \\
\hline
\end{tabular}

oxygen overpotencial. The addition of $0.1 \%$ $\mathrm{CoSO}_{4}$ in an electrolyte containing $3.35 \mathrm{M} \mathrm{H}_{2} \mathrm{SO}_{4}$ leads to a decrease of the potential by $50 \mathrm{mV}$ (at low current densities) ${ }^{[32 \text { and 33] }}$. The corrosion of an electrolyte $\left(\mathrm{H}_{2} \mathrm{SO}_{4}+\mathrm{Cu}^{2+}+\mathrm{Mn}^{2+}\right)$ on a lead anode is much lower to that observed with the same electrolyte with Co instead of $\mathrm{Mn}$ ions ${ }^{[11]}$.

As an average, EW plants in Chile produce around $2 \mathrm{kton} /$ year of solid lead as slime. This residue is stored with no further treatment. The average rate of corrosion in Chilean EW plants is approximately $0.2 \mathrm{~kg} \mathrm{~Pb} /$ anode/day.

Table II shows a typical slime composition. The main constituent is lead in the form of sulfate, which is produced only by corrosion of the anode. The copper in the slime is originated from the cathode control operations. It is common to cut off any dendrite-form growing on the copper deposit surface, which avoids short-circuits. The iron present in the slime is due to mechanical entrapment of the EW electrolyte during removal

Table II. Typical Chilean slime composition from EW Tabla II. Composición típica de una borra de EO chilena

\begin{tabular}{cc}
\hline Component & $\%$ \\
\hline $\mathrm{Pb}$ & 76.6 \\
$\mathrm{Cu}$ & 1.2 \\
$\mathrm{Fe}$ & 0.3 \\
$\mathrm{Mn}$ & 0.2 \\
Other impurities & 1.2 \\
Moisture & 20.5 \\
\hline
\end{tabular}

Rev. Metal. Madrid 40 (2004) 13-20 of the slime from the cell, and it could not be associated to any ferrous- or ferric- based compound precipitate. The manganese is mainly in the form of hexagonal oxide. The presence of iron in the electrolyte indicates that tetragonal manganese oxide is not present since reaction (3) was inhibited. As it was discussed, the iron presence in the electrolyte reduces the manganese in the slime along with its volume, which is in accordance with the relative low levels of manganese observed in Chilean slimes and its formation rate. Other impurities (Table II) are considered the additives (guar and cobalt) and a variety of small amounts of metallic precipitates.

The variability of the slime formation rate is not only closely related to the electrolyte composition, but also in an important grade to the proper control of the operational plant parameter such as short-circuits, electrolyte temperature, anode quality, etc. Figure 8 shows the variability observed in a medium size EW plant with slime formation rates markedly higher than the national average of $0.2 \mathrm{~kg}$ of slime per day and per cell. Since in this plant the operation has common electrolyte feeding system for all the cells, the significant variability showed in the figure is not due to fluctuations of the electrolyte composition. Since it is also possible to get yield a moderate slime formation rate, as it is shown in cell number 10 , by optimizing the operational parameters of the tankhouse, it could operate under the same condition of moderate slime formation rate.

\section{CONCLUSIONS}

The main conclusions of this work can be summarized as follows:

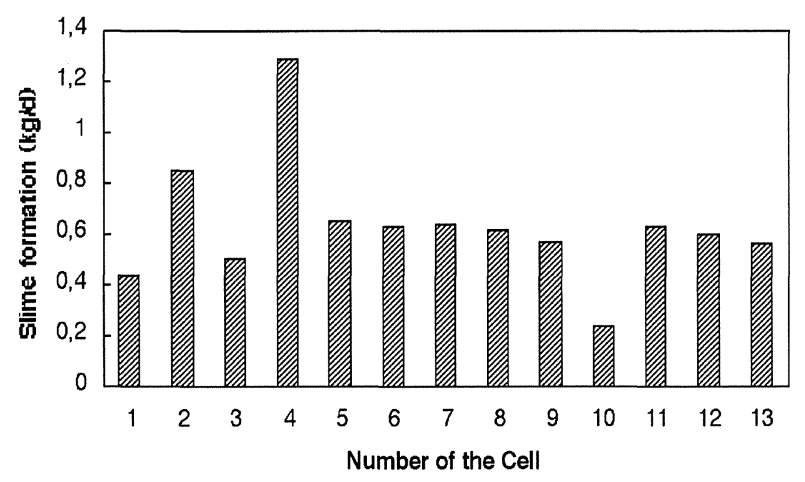

Figure 8. Variability of the slime formation rate within a tankhouse of a medium size EW copper producer.

Figura 8. Variabilidad de la tasa de formación de borras de una planta productora de cobre por EO de tamaño medio. 
- Manganese deposits on the anode surface reduce the presence of lead compounds in the slime, which can operate as a protective effect of this ion on the anodic corrosion.

- Manganese present in slime is hexagonal and tetragonal oxides. The presence of iron in the electrolytes inhibits the formation of tetragonal manganese oxide, reducing the volume of the slime formed.

- The lower slime generation in Chilean EW plants could be due to the lower contents of iron and manganese in the electrolytes.

- The slime formation rate not only is due to the electrolyte composition but also to the right optimization of the operational parameters of the EW plant.

\section{Acknowledgements}

The authors thank to the different Chilean EW plants whose data permit the generation of this work. One of the authors (JPI) thanks to the financial support provided by FONDECYT through the project $3.000 .059 / 2000$.

\section{REFERENCES}

[1] F.J. Alguacil and M. Alonso, Rev. Metal. Madrid 38 (2002) 263-269.

[2] F.J. Alguacil, Rev. Metal. Madrid 39 (2003) 205-209.

[3] P. Ruetshi and R. Angstad, J. Electrochem. Soc. 12 (1964) 111.

[4] P. Mattesco, N. Bui, P. Simon and L. Albert, J. Electrochem. Soc. 144 (1997) 443.

[5] G. Cifuentes, J. Simpson, G. Crisóstomo and L. Cifuentes, Proc. Fourth Int. Conf. Copper 99, Vol. 3, Phoenix (USA), 1999, J.E. Dutrizac et al. (Eds.), TMS, Warrendale, USA, pp. 479.

[6] R. Prengaman and A. Siegmund, Proc. Fourth Int. Conf. Copper 99, Vol. 3, Phoenix, USA, 1999, J.E. Dutrizac et al. (Eds.), TMS, Warrendale, USA, pp. 561.

[7] A. Pagliero and F. Vergara, Proc. Fourth Int. Conf. Copper 99, Vol. 3, Phoenix, USA, 1999, J.E. Dutrizac et al. (Eds.), TMS, Warrendale, USA, pp. 528.

[8] A. Pagliero and F. Vergara, Curso: Normalización de la calidad y comportamiento de ánodos, Universidad de Concepción, Antofagasta, Chile, 2000.

[9] R. Newnham, J. Appl. Electrochem. 22 (1992) 116-124.

[10] M. Fleischmann, H. ThirsK and L. Tordesillas, Trans. Faraday Soc. 58 (1962) 1865-1877.

[11] K. Ravindran, L. Heerman and L. Van Simabys, Bull. Soc. Chim. Belg. 84 (1975) 83-90.

[12] J. BRENET, Electrochim. Acta 1 (1959) 231-241.
[13] C.Y. Cheng, C.A. Hughes, K.R. Barnard and K. LARCOMBE, Hydrometallurgy 58 (2000) 135-150.

[14] D.R. Shaw, J. Illesca, C. Tomasek, S. Jupp, D. Dreisinger, B. Wassink, D. REAdETT and T. LANCASTER, Proc. Fourth Int. Conf. Copper 99, Vol. 3, Phoenix, USA, 1999, J.E. Dutrizac et al. (Eds.), TMS, Warrendale, USA, pp. 653-668.

[15] G. Miller, Proc. Fourth Int. Conf. Copper 99, Vol. 3, Phoenix, USA, 1999, J.E. Dutrizac et al. (Eds.), TMS, Warrendale, USA, p. 649.

[16] F. Vergara, A. Pagliero y J. Ipinza, Proc. IBEROMET VI, Barcelona, España, 2000, J.M. Guilemany et al. (Eds.), CENIM-CSIC, pp. 167-174.

[17] A. Pagliero, F. Vergara, J. Ipinza y J. Delplancke, Proc. II Encuentro Minero del Cono Sur de América, Iquique, Chile, 2001, J.P. Ibáñez et al. (Eds), Universidad Arturo Prat, p. 123.

[18] M. Chigane and M. IshiKawa, J. Electrochem. Soc. 147 (2000) 2246-2251.

[19] F. Varela, L. Gassa and J. Vilche, J. Appl. Electrochem. 25 (1995) 364-370.

[20] T. SubBaiah and S. DAS, Hydrometallurgy 36 (1994) 271 283.

[21] O. TINKLeR, Acorga Notes, Metal Extraction Products, Issue 6, Phoenix, USA 2002.

[22] I. Ivanov, Y. Stefanov, Z. Noncheva, M. Petrova, Ts. Dobrev,L. Mirkova, R. VermeErsch and J.P. Demaerel, Hydrometallurgy 57 (2000) 109-124.

[23] P. Yu and T. O'KeEFe, J. Electrochem. Soc. 146 (1999) 1361-1369.

[24] P. Ruetschi, J. Electrochem. Soc. 123 (1976) 495-500.

[25] E. Rocca, J. Steinmetz and S. Weber, J. Electrochem. Soc. 146 (1999) 54-58.

[26] D. Pavlov and B. Monahov, J. Electrochem. Soc. 143 (1996) 3616-3628.

[27] Y. GuO, J. Electrochem. Soc. 140 (1993) 3369-3373.

[28] J. Ipinza, J.P. Ibáñez, F. Vergara y A. Pagliero, Proc. Hydrometallurgy 2003- Fifth Int. Conf. in Honour of Prof. Ian Ritchie, Vol. 2, Vancouver, Canada, 2003, C. Young et al. (Eds.), TMS, Warrendale, USA, pp. 1267-1277

[29] J. IPINZA, J.P. IBÁÑNZZ and J. ARAGÓN, to be submitted to Rev. Metal. Madrid (2004).

[30] J.P. IbÁÑez, A. MAYorga and L. Cifuentes, to be submitted to Rev. Metal. Madrid (2004).

[31] J. IPINZA, J.P. IBÁÑEZ and J. ARAGÓN, to be submitted to Hydrometallurgy (2004).

[32] I. Ivanov, Y. Stefanov, Z. Noncheva, M. Petrova, TS. Dobrev, L. Mirkova, R, Vermeersch y J.P. Demaerel, Hydrometallurgy 57 (2000) pp. 125-139.

[33] A. Pagliero, F. Vergara y P. Andrade, Proc. I Encuentro Minero del Cono Sur de América, Iquique, Chile, 1998, J. Aragón et al. (Eds.), Universidad Arturo Prat, pp. 362. 371. 